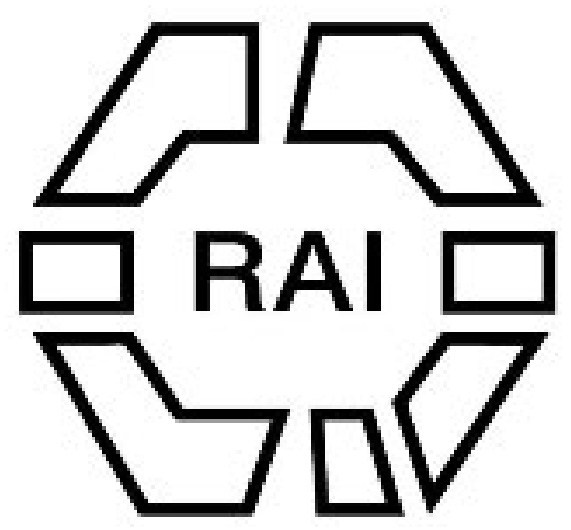

Notes on Prehistoric Remains in Antiparos.

Author(s): Theodore Bent

Source: The Tournal of the Anthropological Institute of Great Britain and Ireland, Vol. 14 (1885), pp. 134-141

Published by: Royal Anthropological Institute of Great Britain and Ireland

Stable URL: http://www.jstor.org/stable/2841851

Accessed: 14/06/2014 18:11

Your use of the JSTOR archive indicates your acceptance of the Terms \& Conditions of Use, available at http://www.jstor.org/page/info/about/policies/terms.jsp

JSTOR is a not-for-profit service that helps scholars, researchers, and students discover, use, and build upon a wide range of content in a trusted digital archive. We use information technology and tools to increase productivity and facilitate new forms of scholarship. For more information about JSTOR, please contact support@jstor.org. 
The following paper was then read by the author, who illustrated his remarks by the exhibition of a large and interesting collection of antiquities from Antiparos:-

\section{Notes on Prehistoric Remains in Antiparos.}

By Theodore Bent, Esq.

I CHOSE the island of Antiparos as a profitable point for making prehistoric researches for several reasons. Firstly, the island is scarcely alluded to at all in historic times; in fact, the only allusion I can find is in Stephanos Byzantios, who says, "Oliaros (that is the ancient name of Antiparos) is one of the Cyclades about which Heracleides of Ponticus, in his account of the islands, tells us it was a colony of the Sidonians, distant from Paros about nine stadia." Secondly, there are no remains of historic times on the island, no trace of temples, walls, or buildings of any kind. Thirdly, I became aware that the island was covered with extensive graveyards, which argued at some time or another an extensive population. It is true that every island in the $A g æ a n$ sea, every barren rock, has graveyards of a sirnilar nature, but then I thought it wisest to choose an island about which there were no historic records, and at the same time evidences of a population even more extensive than in the others, and if these had been in existence in historic times they could not have been passed over in silence.

As yet but few steps have been taken in discovering the ethnological distinctions of this vast prehistoric empire which inhabited the Greek islands. Dr. Schliemann's researches at Hissarlik bear on this subject, but the prehistoric inhabitants of Troy and the prehistoric inhabitants of the Cyclades must have had wide differences between them. The French school at Athens made valuable discoveries at Therasia, adjacent to Santorin, and forming a part of the same volcanic formation; but here again we have differences, which I will presently explain.

Having thus elected to make excavations at Antiparos, I set to work to discover the extent of the graveyards. I visited no less than four of them on the island itself, and heard of the existence of others. An adjacent rock in the sea is covered with them, and a small island between Antiparos and an uninhabited island called Despotico is still termed Cemiterio, from the cemetery which exists there; likewise in Despotico I visited two more similar graveyards, and I may add here that this island and Antiparos were once joined by a tongue of land. With the aid of the glass used by the sponge fishermen to 
examine the bottom of the sea, I saw traces of dwellings in the sea, a well, an oven, and a small square house; unfortunately they were too covered with seaweed for me to form any opinion about them. It would be interesting, if possible, to compare them with the houses found at Therasia and Santorin by the French. It is on a hill just above this point that an extensive graveyard exists; it is possible, then, that these submerged dwellings formed the town of which this was the necropolis.

Again, the marble quarries of Paros made that island a great certre for settlements in all ages, probably by people of various races and languages. Paros, too, on the eastern side, is a perfect necropolis, and produces many specimens like those I show to-day, but Paros had a large population in historic times, which Antiparos had not, so I deemed it wiser to confine my researches chiefly to the latter island.

During my stay there I opened about forty graves in two different graveyards. The one to the west, just over the submerged town I mentioned above, was greatly inferior to the other on the south-eastern side of the island, both as to wealth and the artistic skill displayed in the articles in them; on the west I found no personal ornaments or obsidian implements, whereas the others were full of them. In the poorer graves we found the rudest marble representations of the human form. In the other graveyard I found the better-shaped figures with a decided advance in artistic skill; they have been made by filing away the marble with some implement, so as to leave the various parts of the body. We can here distinctly trace the nose, the eyes, and the mouth; the female figures have received special attention, and the idea of a sitting posture is given in one, and the calves of the leg are cleverly rounded. The one with pointed legs, I take, by comparing it with a specimen in the British Museum, to be a man: he was found in the same tomb as the woman. From the island of Amorgos I got a still unore advanced specimen of these quaint figures: the trunk of a woman's body with an arm of another body round her back. In the museum at Athens there is a yet more perfect figure from Amorgos : a man sitting in a chair playing a harp, really a work of fair execution; but one and all have a peculiarly unnatural shape of the head, and it is puzzling to divine why, when they could round and finish off the other parts of the body, they persistently made the head pointed. In some graves I found legs all alone; in another a headless silver figure; in others round Hat bits of marble which I threw away as mere pebbles at the time, but after-consideration makes me think that they were perhaps intended for the same purpose. Doubtless these figures had some religious purport, and from the excess of female 
figures over male, it is presumable that the people were worshippers, though not exclusively, of some female deity. In our travels through the various islands we saw lots of these figures in the peasants' houses; but they invariably considered them as valuable as the Venus of Milo, and not entertaining the same idea myself, I failed to become possessed of them.

Again, as I said before, in the poorer graves I found no obsidian knives or cores, whilst in the richer ones they were abundant; but here again I found none of these obsidian arrowheads, which occur in quantities in Santorin and other places where obsidian implements existed. As the prehistoric Antipariotes had obsidian close at hand on the mountain side, I take it that these graves must date from the first introduction of the use of obsidian, there being none of it in the poorer graves, and nothing but knives in the richer ones. Obsidian, of course, is found in abundance in other parts of the world; cores of it come from Hungary, from Mexico, from Tierra del Fuego. Cerro de Navajas is an obsidian hill in Mexico, formerly the Sheffield of the place before the Spanish invasion, and Cortes found the barbers of the Aztec capital shaving natives with obsidian razors. The art of making them has perished, but the theory is plain: any maker of gun-flints could do it. The Indians still have a plan of working obsidian, by laying a bone wedge on the surface of a core, and tapping it till the stone cracks, and their productions are the same as these specimens from Antiparos.

The marble found in both graveyards shows considerable skill in the working of it: vertical holes for suspension $(a v \chi \nu a \rho \iota a)$ and neatly rounded bowls, well-formed plates, and edges of different design, either a rim or bits left for ornament-all these show a great deal of skill; in fact, marble is a speciality of the Cyclades, and was doubtless, even in those times, an article of commerce, so we can hardly be surprised at a proficiency in working it existing at the very fountain head.

As to the metal ornaments found in the richer graves, they are all of very rude workmanship. A narrow twisted tongue is of silver with a large percentage of copper in it; rings of silver with the same incrustation as on certain rings found in Etruria, which cuts like horn; a band of bronze with a high percentage of copper, with an incrustation of red oxide and green carbonate of copper; and then the little silver image with a thick incrustation of chloride of silver; thus giving us silver, copper, and bronze in use at the date of these graves.

But of course the pottery is after all the most important item, and demands our chief attention, and in the poorer graves we seldom found anything else. It is important to note that, for the first time, these marble figures are associated with pottery. It 
is all very rude, though there exists a good deal of artistic decoration closely akin to that on the pottery found in British barrows. The vase shaped like a sea urchin, if its spines were closed, is perhaps the best specimen I found, and on early Greek glass vessels the same decoration is observed. Most of them are very true in shape-too much so to be hand made, and we may presume that some at least were turned on a wheel. Of the incised patterns, none appear to be taken from vegetable or animal life, all being herring-bone or criss-cross; this would place our pottery anterior to that of Hissarlik, on which we see attempts at the representation of eyes, noses, and breasts. The clay is very poor, and very slightly baked; much of it is black inside, as if the pots had been dried in a closed place, so that the smoke had penetrated the clay before they were baked. I may here say it is always fragile when first found. Then again we have specimens with bits of marble in the clay to prevent its contracting. Of course no importance can be attached to the following facts, but it is worthy of remark that in a cavern in Andalusia, fragments of a vase, now in the Museum of St. Germain-en-Laye, were found with vertical tubular holes for suspension, exactly like those before us now. Similar ones have been found in Breton dolmens, and in the Museum of Nordiske Oldsager, at Copenhagen, is a vase found in Denmark, exactly like this one, covered with a lid, and having on each side corresponding perforations, through which strings could be passed. This one came from the richest grave I opened on the south-east side. A vase in the British Museum, from Porth Dafarch, in Anglesea, has exactly the same pattern on as this one, and bits of marble or quartz in the clay to prevent contraction are often seen in ancient British vases. Furthermore, figures similar to these have been found in Danish barrows, but not of marble. These points of course prove nothing, yet they are curious as prehistoric coincidences.

I must here add a noteworthy fact: I opened a small isolated grave under a projecting rock almost 200 yards from the western graveyard. In it I found the bones of a child and a lamp and pot, of a much more recent date; the grave was made in exactly the same form as the others. It is perhaps the grave of a child who died at sea, and the materials and method for making the grave were taken from the neighbouring grave. Even now. caïques remain weatherbound for weeks together in the harbour just below, and this may account for the presence of another vase of a more recent date which I found in one of these graves.

And now a few words about the graves themselves. In the first place those on the western slope are very irregular in shape : some oblong, some triangular, some square; they generally had VOL. XIV. 
three slabs to form the sides, the fourth being built up with stones and rubbish. There was always a slab on the top, and sometimes at the bottom of the grave. They were on an average 3 feet long, 2 feet wide, and seldom more than 2 feet deep. In every grave here we found bones, chiefly heaped together in confusion, and most of the graves contained the bones of more bodies than one. In one very small grave we found two skulls, so tightly wedged together between the side slabs that they could not be removed whole. From this we argued that the flesh had been removed in some way before interment, differing from what Dr. Schliemann found at Hissarlik, where he says, "All prehistoric people who succeeded each other in the course of ages on the hill of Hissarlik, used cremation of the dead." I brought home one skull to Dr. Garson, and several bones.

The graves to the south-east of the island were considerably larger, and better built, containing only one body in each. Some of these were double graves, one above and one below, and in every case there was a slab or pillar on which the head rested. Curiously enough, the grave which contained most ornaments, obsidian knives, and the pot with a lid, had no bones in it. I have had the earth tested, but there are no traces of cremated bones.

Without the aid of geology nothing can be decided as to the dates of these graves; but with the assistance of geology something might be done. It would perhaps turn on two points: when was the first great convulsion of nature which changed Santorin from a lovely island called $K a \lambda \lambda i \sigma \tau \eta$ into a mass of pumice, and when were the houses in the sea at Antiparos submerged by the breaking through the tongue of land between Antiparos and Despotico?

No tradition or allusion occurs in Herodotus, or any other early writer, about that stupendous volcanic eruption at Santorin, the effect of which must have been quite as severe as the recent occurrence in the Sunda Straits, and Herodotus gives us the traditions of Santorin as far back as the sixteenth century B.c. M. Fouqué, the French geologist who went to Santorin to study the recent eruption in 1870, stated it as his opinion that the first convulsion must have taken place twenty centuries before Christ. Tradition and geology hence combine in placing the event before the sixteenth century, and the discoveries made by the French school were of villages, prior to that event, which had been buried deeply in pumice. Except in the one point of marble, the finds at Antiparos point to a much ruder civilisation than these at Santorin, and considering the proximity of the two islands, and the large population on each, it is hardly likely that the art of making good pottery would exist in one island, and 
be unknown in the other. M. Fouqué proves satisfactorily, furthermore, that considerable commerce existed between his prehistoric people and the neighbouring islands, as he found pots made of clay from Anaphi and other proofs of intercourse.

In searching for the date of this vast population which inhabited the islands of the Agran sea, we are therefore carried back into the remotest antiquity, and perhaps all we can surmise is that they existed prior to the sixteenth century before Christ. From observation, I am convinced that the largest population at this period was at Paros, whereas Amorgos has furnished the richest finds. I may add here that I was told when in Amorgos that a similar grave had been opened, containing the bones of twelve individuals and several pieces of pottery and images. For this I cannot vouch, but it is quite possible, as we found the remains of three, and sometimes four, in one grave at Antiparos, and after a battle or a plague it might have been found convenient to bury in this way.

I am convinced that by a further pursuit of this subject, and by a more vigorous system of excavation than I was able to apply to it, much more of interest may be obtained, and further light thrown on the primitive race of mankind who inhabited the islands of the Egæan Sea.

\section{Discussion.}

Dr. Garson said that the skull from the tombs of Antiparos placed in his hands for examination by Mr. Bent, was that of an adult male of middle age. In general appearance it strikes one as being remarkable: short antero-posteriorly, and deep from above downwards in the parieto-occipital region, which is due to the rapidity with which the occiput curves downward towards the foramen magnum from the middle of the parietal region. The shortness of the cranium seems to be counterbalanced by the fulness downward of the cerebellar fossae. The cephalic or breadth index is 80.9 , which shows the skull to be brachycephalic. The basio-bregmatic height-index is $79 \cdot 2$, very nearly the same as the breadth index. The face is orthognathous, the alveolar index being $87 \cdot 1$. The nose is mesorhine, with an index of $51 \cdot 0$. The orbits are fairly large and rounded, their index being $84^{\circ} 6$, showing that they are mesoscene. The parietal tubera are well marked, the glabella is fairly prominent, and metopism, or persistence of the frontal suture, is present.

Comparing this skull with the Greek skulls in the College of Surgeons museum, we find it most nearly agrees in general appearance with one obtained from an ancient tomb at Ruvo, in Magna Græcia, which was found to be rich in Grecian relics; this latter, however, is considerably more dolichocephalic, as are also the Greek skulls in this museum, with the exception of one from Nola, a Chalcedic colony. I have not had an opportunity of examin- 
ing the ancient Greek skulls in the museum of Netley Hospital, but from the account of them given by Dr. Williamson, dolichocephaly seems to be the rule among those also. For the sake of comparison I have placed side by side with the measurements of this skull from Antiparos those of what is usually considered to be a typical Grecian skull obtained from Cuma, an Eolic colony, from which it will be seen that the former differs considerably.

The small amount of material we possess of the ancient Greeks renders this a very acceptable and valuable addition, and it is earnestly to be hoped that more skulls, and if possible, skeletons, or at least the long bones, will be obtained and placed in our museum, so as to enable us to study the osteological characters of this once great and famous nation, more fully than is possible at present. It is very desirable also to procure some more skulls and skeletons from the same tombs in Antiparos, so that we may be able to decide whether the characters presented by this skull are peculiar to it, or are of a racial nature.

\begin{tabular}{|c|c|c|c|c|c|c|}
\hline & & & & $\begin{array}{l}\text { ll fron } \\
\text { tiparos }\end{array}$ & & $\begin{array}{l}\text { Skull from } \\
\text { Cuma. }\end{array}$ \\
\hline Length (maxin & & $=0$ & . & 178 & .. & \\
\hline Breadth (maxi & in) & .. & .. & 144 & .. & 139 \\
\hline Cephalic index & .. & .. & .. & $80 \cdot 9$ & .. & $73 \cdot 9$ \\
\hline Height & .. & .. & .. & $14 i 1$ & .. & 129 \\
\hline Height index & 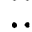 & & .. & $79 \cdot 2$ & .. & $68 \cdot 6$ \\
\hline Circumference & ori & & $\ldots$ & 510 & .. & 525 \\
\hline Basio-nasial ler & & $\therefore$ & .. & 101 & .. & 105 \\
\hline Basio-alveolar & .. & .. & .. & 88 & .. & 102 \\
\hline Alveolar index & .. & .. & . & $87 \cdot 1$ & .. & $97 \cdot 1$ \\
\hline Nasal length & .. & .. & .. & 51 & .. & 53 \\
\hline Nasal breadth & .. & .. & .. & 26 & .. & 25 \\
\hline Nasal index & .. & $\cdots$ & & 51 & .. & $47 \cdot 2$ \\
\hline Orbital width & .. & .. & .. & 39 & .. & 37 \\
\hline Orbital height & .. & .. & .. & 33 & .. & 35 \\
\hline Orbital index & $\bullet$ & $\cdots$ & & $84 \cdot 6$ & 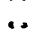 & $86 \cdot 7$ \\
\hline
\end{tabular}

Mr. Hyde ClaRke said the objects brought before them by Mr. Bent, and illustrated by Dr. Garson, were of particular value as confirming the researches communicated by himself to the Institute and to the Royal Historical Society, as to the early epoch of culture. All discoveries tended in the same direction of throwing back the origin of culture to a period more remote than was generally contemplated. What had been regarded as original in Egypt and Babylonia were now known to have been developments from an antecedent epoch. Thus even the Akkad was felt to have had its predecessor. There were still notions prevalent that Phonician or Egyptian sources were to be assigned as the origin of everything. He was not surprised that Dr. Garson did not find the skull to agree with Grecian skulls. For it was to be remembered that the period with which Mr. Bent dealt was one before the Aryans appeared on the scene, and it was rather to be expected, as he himself had stated, that members of several races took part in the settlements at Antiparos and elsewhere, speaking, as he had shown in the paper on the Autonomous Coins, 
distinct languages. It was quite within compass that higher and ruder forms were contemporaneous, while if a slave race survived its leaders, the inferior workmanship would also survive. The communication of Mr. Bent was to be regarded as of great importance, as Antiparos was of decidedly prehistoric or protohistoric character. Calamine had lately been discovered in Antiparos, and the working of this in prehistoric times may account for the large population, as the abandonment wonld for the departare of the inhabitants at a later date.

\section{JUNE 10TH, 1884.}

Professor W. H. FLower, LL.D., F.R.S., President, in the Chair.

The Minutes of the last meeting were read and signed.

The following presents were announced, and thanks voted to the respective donors:-

For the Library.

From the AutHor.-Nègres et Civilisation Egyptienne. By Gabriel de Mortillet.

Sur la Fossette Vermienne du Crâne des Mammifères. By M. le Professeur Paul Albrecht.

The Temple of the Andes. By R. Inwards.

From the German Anthropological Society.-Correspondenz-Blatt. April, May, 1884.

From the Royal Academy of Copenhagen.-Oversigt over det Kongelige Danske Videnskabernes Selskabs. 1883, No. 3; 1884, No.1.

From the ACAdemy.-Bulletin de l'Académie Impériale des Sciences de St. Petersbourg. Tom. XXIX, No. 2.

From the Association.-Journal of the East India Association. Vol. XVI, No. 3.

From the Musedm.-Annual Reports of the Peabody Museum, 16, 17. From the Socierry.-Bulletin de la Société d'Anthropologie de Bruxelles. Tom. II, Fas. 3.

Proceedings of the Royal Geographical Society. June, 1884. From the EDITOR.- "Nature." Nos. 761, 762.

Revue Politique et Littéraire. Tom. XXXIII. Nos. 22, 23 ,

Revue Scientifique. Tom. XXXIII, Nos. 22, 23.

"Science." Nos. 67, 68.

The Science Monthly. Vol. I, No. 8.

The following Paper was read by the Director :- 